\title{
Damselflies (Zygoptera) as paratenic hosts for Serpinema trispinosum and its report from turtle hosts from Oklahoma, USA
}

\author{
Crystal M. Wiles and Matthew G. Bolek
}

Department of Zoology, Oklahoma State University, Stillwater, Oklahoma, USA

\begin{abstract}
Third-stage larvae of the nematode Serpinema trispinosum (Leidy, 1852) were collected from the midgut of four of five species of adult damselflies (Zygoptera) from a non-irrigated restored semipermanent wetland located in Stillwater, Oklahoma, USA. Of the four infected damselfly species, prevalence and mean abundance was highest for the southern spreadwing, Lestes disjunctus australis Walker $(10 \%, 0.2 \pm 0.8)$ and lowest for the familiar bluet, Enallagma civile (Hagen) $(2.5 \%, 0.04 \pm 0.3)$; whereas mean intensities were lowest for the citrine forktail, Ischnura hastata (Say) $(1.5 \pm 0.5)$ and the eastern forktail, Ischnura verticalis (Say) $(1.0 \pm 0)$. This is the first record of larvae of S. trispinosum from damselflies. Serpinema trispinosum adults have been reported from 18 species of North and Central American freshwater turtles, whereas microcrustaceans such as copepods serve as intermediate hosts and snails, fish and amphibians serve as paratenic hosts in this nematode's life cycle. However, dietary studies of the 18 species of freshwater turtles reported as definitive hosts for $S$. trispinosum indicate that aquatic insects including damselflies are more commonly reported in turtle diets than are fish or amphibians. Additionally, unlike snails and amphibians, larval damselflies predominantly feed on microcrustaceans, and our observation of S. trispinosum infecting damselflies may reflect the importance of these insects as paratenic hosts. In the present study, we provide new host information and measurements for third-stage larvae of S. trispinosum from damselfly hosts along with measurements for adult male and female $S$. trispinosum from turtle hosts from Oklahoma, USA.
\end{abstract}

Keywords: Damselflies, nematodes, paratenic hosts, turtles, morphology

Although damselflies are commonly surveyed for parasites, few studies report nematodes from these hosts (Willis 1971, Corbet 1999, Baker 2011, Novak and Goater 2013). As a result, very little is known about the host specificity and distribution of nematodes in odonates (see Corbet 1999, Baker 2011). One such species is Serpinema trispinosum (Leidy, 1852) (Camallanidae), an intestinal nematode that infects New World turtles as definitive hosts (Baker 1979, Moravec and Vargas-Vázquez 1998a). Although the complete life cycle of $S$. trispinosum has not been elucidated, evidence suggests that the life cycle resembles that of other camallanid nematodes which infect copepods as intermediate hosts, numerous invertebrate and vertebrate paratenic hosts and vertebrate definitive hosts (Baker 1979, Moravec and Vargas-Vázquez 1998a, Hoffman 1999).

The only published information on a partial life cycle of S. trispinosum was provided by Moravec and VargasVázquez (1998a). These investigators infected laboratoryreared copepods Macrocyclops albidus (Jurine) with firststage larvae of $S$. trispinosum recovered from adult worms collected from red-eared slider turtles Trachemys scripta (Schoepff). Moravec and Vargas-Vázquez (1998a) found that $S$. trispinosum developed to second-stage larvae in M. albidus.

Additionally, field studies by Moravec and VargasVázques (1998b) and others (Bartlett and Anderson 1985, Cabrera-Guzmán et al. 2007, 2010, González and Hamann 2007) recovered nematode third-stage larvae that conformed to the description of $S$. trispinosum from a variety of naturally infected paratenic hosts. These paratenic hosts included the Mayan cichlid, Cichlasoma urophthalmus (Günther), from Mexico, five species of anurans including Lysapsus limellum Cope, Lithobates catesbeianus (Shaw), L. clamitans (Latreille), L. forreri (Boulenger) and L. pipiens (Schreber) from various locations in North, Central and South America, and the great pond snail, Lymnaea stagnalis (Linnaeus), from Canada. These authors hypothesised that paratenic hosts became infected with this nematode when they ingested infected copepods, whereas turtle definitive hosts become infected when they ingest paratenic hosts or copepod intermediate hosts infected with $S$. trispinosum.

While S. trispinosum larvae have been reported from various groups of invertebrates and vertebrate paratenic hosts, until now no reports are known from zygopteran 
hosts (Bartlett and Anderson 1985, Moravec and VargasVázquez 1998b, González and Hamann 2007). This observation is an important one because both laboratory and field surveys indicate that copepods, the intermediate hosts for $S$. trispinosum, are an important component in the diet of larval zygopterans (Corbet 1999) and more so than in the diets of aquatic snails, amphibians or some fish (Baker 1928, Becker 1983, Dillon 2000, Bolek et al. 2010).

Therefore, our observations of $S$. trispinosum infecting zygopterans may reflect the importance of damselflies as paratenic hosts for this genus of nematodes. In the present study, we provide new host and geographical distribution information for larvae and adult $S$. trispinosum from damselfly and turtle hosts from Oklahoma along with measurements for larvae, and adult male and female $S$. trispinosum. Additionally, we review the literature on the diet of all species of turtles reported as definitive hosts of S. trispinosum and argue that damselflies may be important paratenic hosts in the life cycle of this nematode.

\section{MATERIALS AND METHODS}

\section{Damselfly collection and necropsy}

During September 2010-September 2012, a total of 530 teneral and adult damselflies of five species representing two families were collected from Teal Ridge Stillwater, Payne County, Oklahoma, USA. (36 $\left.6^{\prime} 1 " \mathrm{~N} ; 9^{\circ} 4^{\prime} 51^{\prime \prime} \mathrm{W}\right)$. These included 5 blue-fronted dancers, Argia apicalis (Say); 278 familiar bluets, Enallagma civile (Hagen); 140 citrine forktails, Ischnura hastata (Say); and 65 eastern forktails, Ischnura verticalis (Say) (all Coenagrionidae) and 42 southern spreadwings, Lestes disjunctus australis, Walker (Lestidae). All damselflies were collected between 9:00 AM and 6:00 PM with an aerial net, placed in a one litre, covered plastic jar, and stored on ice until transport to the laboratory. However, not all species or life stages were collected each year. In the laboratory, all damselflies were identified to species, stage and sex based on descriptions and keys in Abbott (2005, 2011), Westfall and May (2006) and May and Dunkle (2007).

Total body length and head width were recorded for each individual damselfly to the nearest $1.0 \mathrm{~mm}$ and $0.1 \mathrm{~mm}$, respectively. Each teneral or adult zygopteran was then killed by removing the head. At necropsy, the abdominal sterna of individual damselflies were peeled back in odonate saline (Fielden 1960). Next, the entire gut was removed and gently teased apart with forceps on a microscope slide, and examined for larval nematodes. Nematodes were fixed in $70 \%$ ethanol and cleared in glycerol according to Pritchard and Kruse (1982). Pearson's correlations were calculated for damselfly total body length and head width and S. trispinosum intensity and abundance for each infected damselfly species (Sokal and Rohlf 1981).

\section{Turtle collection and necropsy}

Two red-eared sliders Trachemys scripta elegans (Wied) were collected using hoop traps on 25 May 2010 from 41 cut-off lake

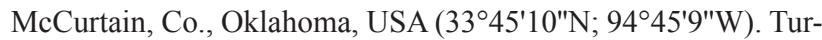
tles were killed by overdose with an injection of sodium barbital. After death, the plastron was removed with a hand saw and all internal organs were removed and examined for helminths. Each organ was placed individually in a petri dish and examined under a stereomicroscope. Sex of turtles was determined by gonadal inspection during necropsy. Nematodes were fixed in $70 \%$ ethanol and cleared in glycerol according to Pritchard and Kruse (1982).

\section{Nematode identification}

Prevalence, mean intensity and mean abundance are reported according to Bush et al. (1997). All values are reported as the mean \pm standard deviation (SD). Nematodes were identified based on descriptions in Baker (1979), Bartlett and Anderson (1985), and Moravec and Vargas-Vázquez (1998a,b). Voucher specimens of third-stage larvae and adult male and female specimens of S. trispinosum have been deposited in the Museum of Southwestern Biology-Parasitology Division, University of New Mexico, Albuquerque, NM, USA (accession numbers MSB Para 19601-19603).

Measurements (6 third-stage larvae, 4 males and 8 females) of this species were taken using a calibrated micrometre on an Olympus BX-51 upright research microscope configured for bright-field and differential interference contrast microscopy with plain fluorite objectives. Digital photographs were taken with an Olympus five megapixel digital camera. All measurements are reported as a range in micrometres unless otherwise indicated.

\section{RESULTS}

\section{Damselfly and turtle infections}

Of the five damselfly species examined only Argia apicalis was not infected with Serpinema trispinosum (Table 1). A total of 29 third-stage larvae of $S$. trispinosum were recovered from the midgut of 6 tenerals and 12 adults of the other species of damselflies examined. Of the infected damselflies, prevalence and mean abundance was highest for Lestes disjunctus australis and lowest for Enallagma civile; whereas mean intensities were lowest for the citrine forktail, Ischnura hastata and the eastern forktail, Ischnura verticalis (Table 1). There were no significant correlations in damselfly total body length or head width and intensity or abundance of S. trispinosum for any of the infected damselfly species $(\mathrm{P}>0.05)$.

Both red-eared slider males were infected with 19 male and 16 female, and 28 male and 14 female S. trispinosum, respectively. Morphological measurements for larval worms from damselfly hosts and adult male and female worms from turtle hosts are provided below.

Table 1. Values of infection parameters of third-stage larvae of Serpinema trispinosum in five species of zygopterans collected from Teal Ridge Stillwater, Payne County, Oklahoma.

\begin{tabular}{lccc}
\hline Species & Prevalence (i/e) & $\mathrm{MI} \pm \mathrm{SD}$ & $\mathrm{MA} \pm \mathrm{SD}$ \\
\hline Coenagrionidae & & & \\
Argia apicalis (Say) & $0(0 / 5)$ & 0 & 0 \\
Enallagma civile (Hagen) & $2.5 \%(7 / 278)$ & $1.6 \pm 1.5$ & $0.04 \pm 0.3$ \\
Ischnura hastata (Say) & $3 \%(4 / 140)$ & $1.5 \pm 0.5$ & $0.04 \pm 0.2$ \\
Ischnura verticalis (Say) & $5 \%(3 / 69)$ & $1.0 \pm 0.0$ & $0.05 \pm 0.2$ \\
Lestidae & & & \\
$\quad$ Lestes disjunctus australis & $10 \%(4 / 42)$, & $2.3 \pm 1.5$ & $0.2 \pm 0.8$ \\
Walker & & & \\
\hline
\end{tabular}

i/e - infected/examined; MA - mean abundance; MI - mean intensity. 

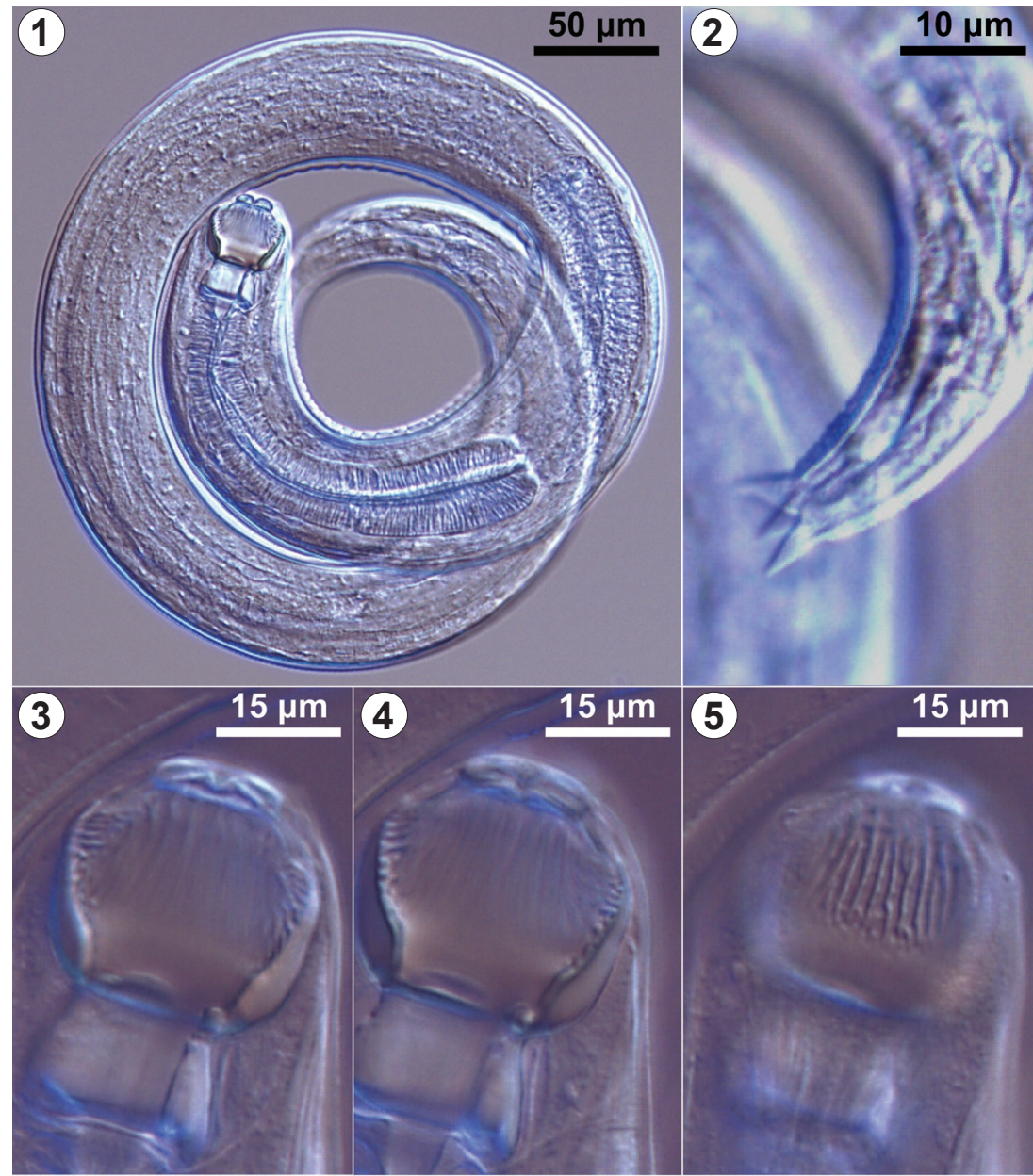

Figs. 1-5. Light photomicrographs of Serpinema trispinosum from the eastern forktail, Ischnura verticalis. Fig. 1. Third-stage larva, general view. Fig. 2. Tail; note the three terminal cuticular spikes. Figs. 3-5. Buccal capsule, lateral view; note ridges in buccal valve.

Family Camallanidae Railliet et Henry, 1915

Serpinema trispinosum (Leidy, 1852)

Figs. 1-13

General: Adult body colour translucent orange to red in life. Medium-sized fusiform worms. Cuticle smooth. Cephalic end with brown buccal capsule consisting of 2 lateral valves. Buccal capsule laterally compressed, composed of 3 parts (2 valves and a basal ring), width and length subequal. Valves marked internally by longitudinal ridges, most numerous near anterior margin of buccal capsule. Anterior margin of valve with 2 small elongate and sclerotised plates. Buccal valves supported by dorsoventral tridents on each side, consisting of 3 posteriorly directed, subequal prongs extending beyond basal ring. Tridents attached to buccal capsule by anteriorly directed divided process supporting each valve. Mouth opening slit-like, surrounded by 4 subapical mouth papillae. Amphids not seen. Nerve ring near posterior end of tridents. Excretory pore slightly posterior to nerve ring. Glandular oesophagus long and slender. Anterior muscular portion clearly divided from posterior glandular portion; latter portion generally equal to muscular portion. Tail with 3 terminal cuticular spikes (mucrons) in larvae and adult females but conical in adult males.

Third-stage larvae (six specimens): Body colourless, 881-1 009 long and 51-63 wide, with smooth cuticle. Buccal capsule divided into anterior globular portion, 25-33 long and 25-33 wide, with inner ridges, and narrower, smooth posterior portion, 20-28 long and 13-15 wide. Each side of anterior portion of capsule bearing more than 10 narrow, long longitudinal ridges extending approximately along anterior two thirds of this portion of capsule, and few (2-3) very short ridges. Posterior portion of capsule simple, thick-walled. Buccal capsule opens into oesophagus through large oesophageal funnel with sclerotised walls. Length of muscular oesophagus 146-202, of glandular oesophagus 108-134; length ratio of muscular oesophagus and glandular oesophagus $1: 0.7-0.8$. Nerve ring and excretory pore 73-91 and 92-98 from anterior extremity, respectively. Genital primordium oval, 625-1046 from anterior end of body. Tail conical, 43-63 long, with 3 terminal cuticular spikes; length of dorsal spike 10-13; of ventrolateral spikes $8-10$.

Males (four specimens): Body length 7.42-9.78 mm and maximum body width $230-267$. Length of entire 

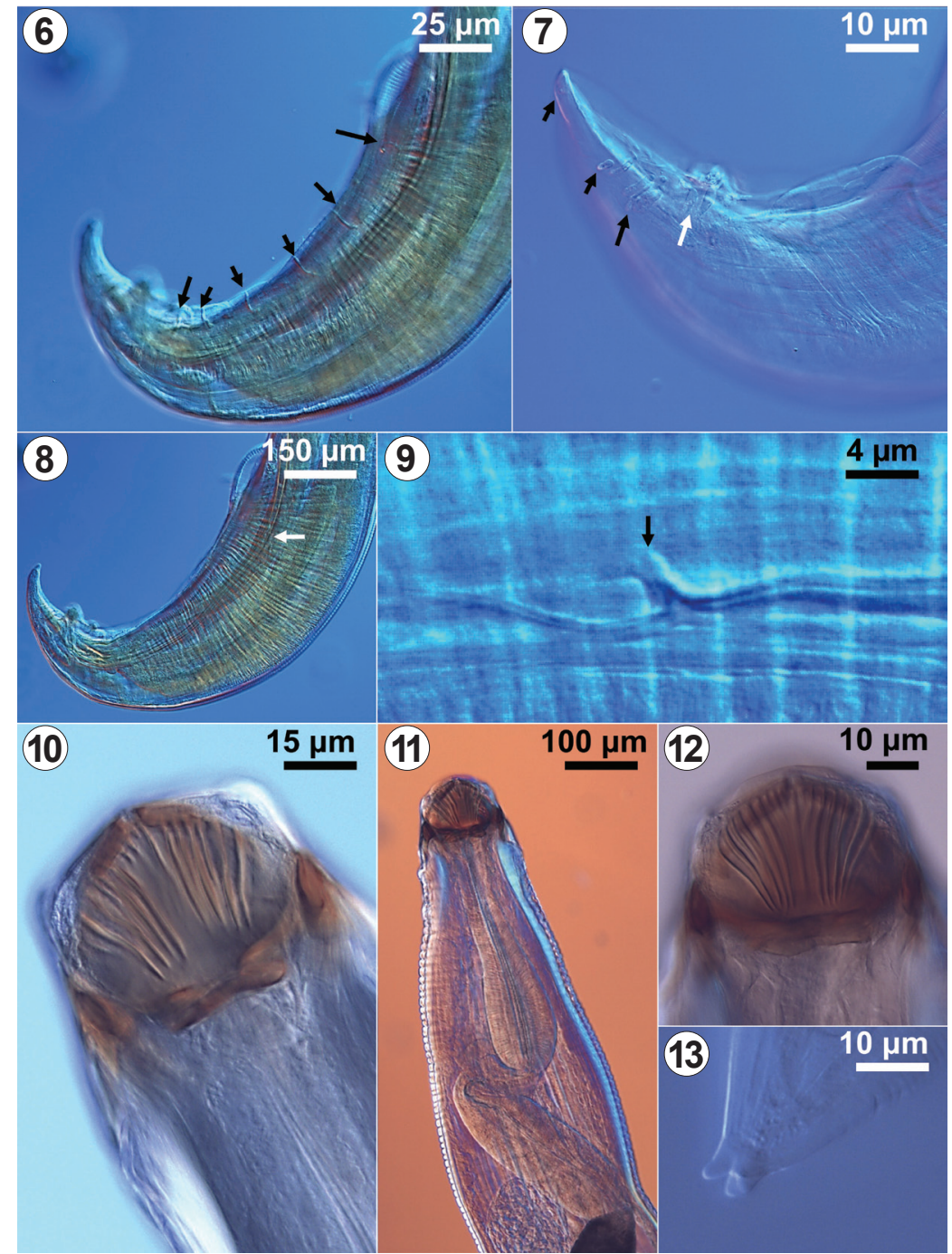

Fig. 6-13. Light photomicrographs of Serpinema trispinosum from Trachemys scripta. Fig. 6. Posterior end of male, lateral view (arrows indicate pedunculate papillae). Fig. 7. Male, posterior, lateral view; note postanal papillae (black arrows) and small sessile papillae (white arrow). Fig. 8. Male, posterior, lateral view; showing well sclerotised large spicule (arrow). Fig. 9. Male, posterior, lateral view; note sharp point and small dorsal barb (arrow) on large spicule. Fig. 10. Male, buccal capsule, lateral view; note ridges in buccal valve. Fig. 11. Female, anterior, lateral view. Fig. 12. Female, buccal capsule, lateral view; note ridges in buccal valve. Fig. 13. Female, tail; note three terminal cuticular spikes.

buccal capsule including basal ring 92-114, buccal capsule width 133-144. Basal ring, 13-16 long and 61-105 wide. Length of tridents, 43-101. Muscular oesophagus, 390-470 long and 102-112 maximum width. Glandular oesophagus 460-614 long and 82-139 wide. Deirids, nerve ring and excretory pore located 459-614, 100-112 and 368-384, from anterior extremity, respectively. Posterior end of body with broad caudal alae supported by pedunculate papillae and opaque alae. Caudal papillae: 7 pairs of preanal and 6 pairs of postanal slender, pedunculate papillae present. First 3 pairs of postanal papillae close to one another, next 2 pairs forming group approximately at middle of tail; last pair of small postanal papillae situated laterally near caudal extremity. Cloacal opening surrounded by 2 transverse mounds and appear in lateral view as 2 pairs of small sessile papillae. Large (right) spicule well sclerotised, 650-775 long; its posterior end slender, sharply pointed, bearing small dorsal, posteriorly oriented barb near tip. Small (left) spicule weakly sclerotised, hardly visible, 190-375 long, with simple, sharply pointed end. Tail conical, 115-130 long, its tip rounded.

Females (eight larvigerous specimens): Body length $10.72-11.85 \mathrm{~mm}$ long, maximum body width 320-520. Length of entire buccal capsule including basal ring 92-163, buccal capsule width 112-200. Basal ring 16-25 long and 96-126 wide; length of tridents 41-125. Muscular oesophagus 450-542 long and 123-160 wide. Glandular oesophagus 403-613 long and 100-202 wide. Deirids, nerve-ring and excretory pore located 403-613, 123-160, and 408-454, from anterior extremity, respectively. Vulva equatorial or somewhat postequatorial, 5.14-6.62 mm from posterior end of body. Vagina directed anteriorly. Uterus filled with larvae, 187-315 long and 11-16 wide. Tail conical 225-306 long, its tip bearing 3 cuticular processes 5-6 long. 
Table 2. Morphological characteristics of third-stage larvae of Serpinema trispinosum reported from various paratenic and turtle definitive hosts.

\begin{tabular}{|c|c|c|c|c|c|}
\hline & Present study & $\begin{array}{c}\text { Moravec and } \\
\text { Vargas-Vázquez 1998b }\end{array}$ & $\begin{array}{l}\text { Bartlett and Anderson, } \\
1985\end{array}$ & $\begin{array}{l}\text { González and } \\
\text { Hamann } 2007\end{array}$ & $\begin{array}{c}\text { Moravec and } \\
\text { Vargas-Vázquez 1998a }\end{array}$ \\
\hline Host group & damselflies & fish & snails & anurans & turtles \\
\hline No. hosts collected & 530 & 18 & 25 & 43 & 3 \\
\hline$\%$ (No. infected/No. examined) & $4 \%(20 / 530)$ & $17 \%(3 / 18)$ & $8 \%(2 / 25)$ & $16 \%(7 / 43)$ & $33 \%(1 / 3)$ \\
\hline No. worms measured & 6 & 5 & 2 & 11 & 1 \\
\hline Total length $(\mu \mathrm{m})$ & $881-1009$ & $980-1295$ & $1200-1300$ & $1170-1930$ & 1400 \\
\hline Maximum width & $51-63$ & $50-75$ & $68-76$ & $46-80$ & 95 \\
\hline Buccal cavity anterior length & $25-33$ & $33-38$ & $30-36$ & $37-42.5$ & 45 \\
\hline Buccal cavity anterior width & $25-33$ & $33-40$ & $\mathrm{~N} / \mathrm{G}^{\dagger}$ & $25-43$ & 48 \\
\hline Buccal cavity posterior length & $20-28$ & $18-20$ & $16-20$ & $16-22$ & 36 \\
\hline Buccal cavity posterior width & $13-15$ & $25-28$ & $\mathrm{~N} / \mathrm{G}^{\dagger}$ & $14-29$ & 33 \\
\hline Muscular oesophagus length & $146-202$ & $175-225$ & $216-220$ & $198-305$ & 258 \\
\hline Glandular oesophagus length & $108-134$ & $130-175$ & $174-190$ & $184-275$ & 190 \\
\hline Nerve ring* & $73-91$ & $95-118$ & $84-88$ & $85-135$ & 126 \\
\hline Excretory pore* & $92-98$ & $120-145$ & $140-144$ & $127-159$ & 159 \\
\hline Genital primordium* & $625-1046$ & $638-863$ & $\mathrm{NG}^{\dagger}$ & $\mathrm{NG}^{\dagger}$ & posterior half of body ${ }^{\dagger}$ \\
\hline Length of tail & $43-63$ & $60-70$ & 64 & $53-115$ & 70 \\
\hline
\end{tabular}

* distance from anterior end; ${ }^{\dagger} \mathrm{NG}-$ not given.

\section{DISCUSSION}

Comparisons of measurements of third-stage larvae of Serpinema trispinosum from damselfly hosts and similar data from fish hosts indicate that specimens overlap in most morphological characteristics $(8 / 12)$ with those descriptions by Moravec and Vargas-Vázquez (1998b; see Table 2). In contrast, morphological characteristics of third-stage larvae of S. trispinosum from aquatic snails and anurans overlapped in fewer morphological characteristics (1/12 and 6/12, respectively) with larvae recovered from damselflies (Bartlett and Anderson 1985, González and Hamann 2007). Finally, the third-stage larva of S. trispinosum recovered from a turtle definitive host by Moravec and Vargas-Vázquez (1998a) was much larger than those collected from damselfly paratenic hosts (Table 2).

Recent studies on nematodes of amphibians by Rhoden and Bolek (2011) and Vhora and Bolek (2013) indicate that host-induced morphological variation in size is a common phenomenon in some amphibian nematodes and it may be that $S$. trispinosum experiences similar morphological plasticity in different species of paratenic hosts. However, the most significant distinguishing characteristics for identification of larvae of $S$. trispinosum and other larval camallanids is the morphology of the buccal capsule. Moravec and Vargas-Vázquez (1998a,b) described thirdstage larvae of S. trispinosum recovered from the intestine of the Mayan cichlid, Cichlasoma urophthalmus and the third- and fourth-stage and adults of this nematode species from the intestine of a Trachemys scripta collected in Yucatan, Mexico. They indicated that the buccal capsule of a S. trispinosum third-stage larva is of a Paracamallanustype, which is divided into an anterior globular portion with inner ridges and a narrower and smooth posterior portion. The specimens recovered from damselfly hosts in our study agree with the morphological description of the buccal capsule reported for third-stage larvae of S. trispinosum by Moravec and Vargas-Vázques (1998a,b) and others
(Bartlett and Anderson 1985, González and Hamann 2007; see Figs. 1, 3-5 in the present study).

Morphological characteristics of adult male and female S. trispinosum recovered from Oklahoma red-eared sliders overlapped for most measured characteristics those reported for these nematodes from Mexican red-eared sliders by Moravec and Vargas-Vázquez (1998a; see Table 3 in the present study). Adult nematodes from Oklahoma did not overlap in the range for four of 15 morphological characteristics in males (buccal cavity anterior width, distance of nerve ring and excretory pore from the anterior end and length of tail) and five of 14 morphological characteristics in females (total length, buccal cavity anterior width, distance of nerve ring and excretory pore from the anterior end and location of the vulva from the posterior end) from the description of this species by Moravec and VargasVázquez (1998b; see Table 3 in the present study). More importantly, the buccal capsule morphology was consistent for species of the genus Serpinema Yeh, 1960 as described by Yeh (1960) and Moravec and Vargas-Vázquez (1998a), which was large, orange-brown in colour and consisting of two lateral valves with an inner surface of each valve supported by 16-21 narrow, longitudinal, sometimes incomplete ridges (see Figs. 10-12). Additionally, the male posterior end (Figs. 6, 7), the length and shape of both spicules (Figs. 8, 9), and tail morphology of females (Fig. 13), were consistent with the description of $S$. trispinosum by Moravec and Vargas-Vázquez (1998a).

Along with infecting 18 species of turtle definitive hosts, reports indicate that this nematode infects a wide range of paratenic hosts including fish, frogs, snails and damselflies (Tables 2,4). These observations suggest that $S$. trispinosum is a generalist at the paratenic host level (Table 2). Studies on the diet content of turtle species reported as definitive hosts for S. trispinosum indicate that all four groups of paratenic hosts are ingested by these turtle species (Table 4). However, our discovery of damselflies 
Table 3. Morphological characteristics of adult Serpinema trispinosum reported from red-eared slider turtles collected in Oklahoma and Mexico. All measurements are in micrometres unless otherwise indicated.

\begin{tabular}{|c|c|c|c|c|}
\hline & \multicolumn{2}{|r|}{ Male } & \multicolumn{2}{|r|}{ Female } \\
\hline & $\begin{array}{c}\text { Present study } \\
\text { Oklahoma Sliders }\end{array}$ & $\begin{array}{c}\text { Moravec and Vargas-Vázquez 1998a } \\
\text { Mexico Sliders }\end{array}$ & $\begin{array}{l}\text { Present study } \\
\text { Oklahoma Sliders }\end{array}$ & $\begin{array}{c}\text { Moravec and Vargas-Vázquez 1998a } \\
\text { Mexico Sliders }\end{array}$ \\
\hline No. worms measured & 4 & 5 & 8 & 5 \\
\hline Total length (mm) & 7.4-9.8 & $4.4-7.5$ & $10.7-11.9$ & $7.5-10.4$ \\
\hline Maximum width & $230-267$ & $163-272$ & $320-520$ & $286-326$ \\
\hline Buccal cavity anterior length & $92-114$ & $105-132$ & $92-163$ & $114-150$ \\
\hline Buccal cavity anterior width & $133-144$ & $150-165$ & $112-200$ & $189-195$ \\
\hline Basal ring length & $12-16$ & $12-15$ & $16-25$ & $15-21$ \\
\hline Basal ring width & $61-105$ & $78-87$ & $96-126$ & $99-105$ \\
\hline Trident length & $43-101$ & $87-105$ & $41-125$ & $105-113$ \\
\hline Muscular oesophagus length & $390-470$ & $367-476$ & $450-542$ & $422-449$ \\
\hline Glandular oesophagus length & $460-614$ & $354-558$ & $403-613$ & $490-517$ \\
\hline Nerve ring* & $100-112$ & $195-231$ & $123-160$ & $218-299$ \\
\hline Excretory pore* & $368-384$ & $313-326$ & $408-454$ & $354-394$ \\
\hline Deirids* & $459-614$ & $435-517$ & $403-612$ & $490-517$ \\
\hline Large (right) spicule length & $650-775$ & $696-759$ & - & - \\
\hline Small (left) spicule length & $190-375$ & $207-210$ & - & - \\
\hline $\operatorname{Vulva}^{* *}(\mathrm{~mm})$ & - & - & $5.1-6.6$ & $3.1-5.0$ \\
\hline Length of tail & $115-130$ & 195-231 & $225-306$ & 218-299 \\
\hline
\end{tabular}

* distance from anterior end; $* *$ distance from posterior end.

Table 4. Types of paratenic hosts for Serpinema trispinosum reported in the diet of 18 species of turtle definitive hosts.

\begin{tabular}{|c|c|c|c|c|c|c|}
\hline Family & Turtle species & Odonates & Snails & Fish & Anurans & Reference \\
\hline $\begin{array}{l}\text { Chelydridae } \\
\text { (snapping turtles) }\end{array}$ & Chelydra serpentina (Linnaeus) & + & + & + & + & Ernst et al. 1994 \\
\hline \multirow{14}{*}{$\begin{array}{l}\text { Emydidae } \\
\text { (pond turtles) }\end{array}$} & Chrysemys picta (Schneider) & + & + & - & - & Cooley et al. 2003 \\
\hline & Clemmys guttata (Schneider) & + & + & + & + & Ernst et al. 1994 \\
\hline & Clemmys insculpta (LeConte) & + & + & + & + & Ernst et al. 1994 \\
\hline & Deirochelys reticularia (Latreille) & $+*$ & - & - & + & Demuth and Buhlmann 1997 \\
\hline & Emydoidea blandingi (Holbrook) & $+*$ & + & + & + & Rowe 1992 \\
\hline & Graptemys geographica (LeSueur) & + & + & + & - & Ernst et al. 1994 \\
\hline & Graptemys kohnii (Baur) & + & + & + & + & Carr 1952 \\
\hline & Graptemys pseudogeographica (Gray) & + & + & + & - & Ernst et al. 1994 \\
\hline & Malaclemys terrapin (Schoepff) & - & + & + & - & Ernst et al. 1994 \\
\hline & Pseudemys concinna (LeConte) & $+*$ & + & + & + & Bjorndal et al. 1997 \\
\hline & Pseudemys floridana Carr & $+*$ & - & - & - & Bjorndal et al. 1997 \\
\hline & Terrapene carolina (Linnaeus) & + & + & + & + & Carr 1952, Ernst et al. 1994, Platt et al. 2009 \\
\hline & Trachemys decussate (Gray) & + & - & - & - & Seidel 1990 \\
\hline & Trachemys scripta (Schoepff) & + & + & + & + & Ernst et al. 1994 \\
\hline \multirow{2}{*}{$\begin{array}{l}\text { Kinosternidae } \\
\text { (musk and mud turtles) }\end{array}$} & Kinosternon subrubrum (Lacépède) & + & - & + & + & Ernst et al. 1994 \\
\hline & Sternotherus odoratus (Latreille) & + & + & - & + & Ernst et al. 1994 \\
\hline $\begin{array}{l}\text { Trionychidae } \\
\text { (soft shell turtles) }\end{array}$ & Apalone spinifera (LeSueur) & + & - & + & - & Martinho 2008 \\
\hline Total & & 17 & 13 & 13 & 11 & \\
\hline
\end{tabular}

+ yes; - no; * indicates over $50 \%$ of turtle diet based on frequency of gut contents.

serving as paratenic host for $S$. trispinosum is significant for several reasons. First, turtle diet studies indicate that larval and adult odonates are the most commonly reported food item in most species of turtles (17/18 turtle species) reported as definitive hosts for this nematode, and odonates can make up over $50 \%$ of the frequency of the diet in some of these turtle species (Table 4). Second, copepods, which serve as first intermediate hosts for $S$. trispinosum, are the predominant food items of larval odonates, including damselflies (Corbet 1999, Bolek et al. 2010), suggesting that these insects commonly come in contact with $S$. trispinosum and other nematode species that use microcrustaceans as intermediate hosts.
In fact, Leuckart (1876) reported a calopterygid zygopteran of the genus Agrion Fabricius as a paratenic host for Camallanus lacustris (Zoega, 1776) whose intermediate host is a copepod. Additionally, Moravec and Škoríková (1998) showed experimentally that odonates, including the anisopteran Sympetrum sanguineum (Müller) and zygopteran Coenagrion puella (Linnaeus), serve as paratenic hosts for Anguillicoloides crassus (Kuwahara, Niimi et Itagaki, 1974) the swimbladder nematode of eels, whose intermediate host is also a copepod. Finally, because teneral and adult stages of damselflies were infected with this nematode, this observation provides a more plausible explanation of how semi-terrestrial turtles such as box turtles, 
Terrapene carolina (Linnaeus), which are predominantly terrestrial insect eaters, become infected with this nematode species (Baker 1987).

Although fish, aquatic snails and amphibians are also commonly reported in the diet of turtle definitive hosts for S. trispinosum, numerous field surveys on helminth parasites of fish, aquatic snails and amphibians indicate that these hosts are rarely infected with this nematode (see Baker 1987, Hoffman 1999, Zimmermann et al. 2011). One explanation for the lack of reports of $S$. trispinosum in aquatic snails and anurans may be that both rarely ingest microcrustaceans in their diets. Aquatic snails predominantly feed on algae and detritus, whereas larval and adult anurans feed on algae or larger prey items, respectively, and both ingest microcrustaceans accidentally (Dillon 2000, Thorp and Covich 2001, Bolek et al. 2010).

In contrast, it is less clear why other fish species have not been reported as paratenic hosts for $S$. trispinosum because microcrustaceans are a common component in the diet of some species of fish (Becker 1983). Clearly, laboratory life cycle studies will have to be conducted to test the host specificity of this nematode in fish paratenic hosts to address this issue. Finally, further surveys of zygopterans and other odonates, including anisopterans, are needed to define their role as paratenic hosts in the life cycle of S. trispinosum. We hope that the present study provides an incentive for comprehensive studies on nematodes of damselfly and other odonates, which will help in alleviating the current lack of knowledge on the occurrence, distribution and biogeography of nematodes infecting odonates.

Acknowledgements. We thank Jason Belden and Alisha Powell Oklahoma State University for collecting and providing the turtles for this work. Additionally, we thank three anonymous reviewers for greatly improving this manuscript. This research was conducted under the Oklahoma State University Institutional Animal Care and Use Committee protocol AS-10-2 and all animals were collected under the Oklahoma Department of Wildlife Conservation Special License number 5022.

\section{REFERENCES}

Аввотт J.C. 2005: Dragonflies and Damselflies of Texas and the South-Central United States: Texas, Louisiana, Arkansas, Oklahoma, and New Mexico. Princeton University Press, Princeton, New Jersey, 344 pp.

Аввотт J.C. 2011: Damselflies of Texas: A Field Guide. University of Texas Press, Austin, Texas, 292 pp.

BAKer F.C. 1928: The fresh water Mollusca of Wisconsin. Part. I. Gastropoda. Bull. Wisc. Geol. Nat. Hist. Surv. Univ. Wisc. 70: $1-507$.

BAKer M.R. 1979: Serpinema spp. (Nematoda: Camallanidae) from turtles of North America and Europe. Can. J. Zool. 57: 934-939.

BAKER M.R. 1987: Synopsis of the Nematoda parasitic in amphibians and reptiles. M.U.N., Occas. Pap. Biol. 11: 1-325.

BAKER R.A. 2011: Parasites of damselflies and dragonflies: a review of recent work. J. Br. Dragonfly Soc. 27: 88-104.

Bartlett C., Anderson R. 1985: Larval nematodes (Ascaridida and Spirurida) in the aquatic snail, Lymnaea stagnalis. J. Invertebr. Pathol. 46: 153-159.

BECKER G.C. 1983: Fishes of Wisconsin. University of Wisconsin Press, Madison, Wisconsin, $1052 \mathrm{pp}$.

Bjorndal K., Bolten A., Lagueux C., JaCkson D. 1997: Dietary overlap in three sympatric congeneric freshwater turtles (Pseudemys) in Florida. Chelonian Conserv. Biol. 2: 430-433.

Bolek M.G., Tracy H.R., Janovy J. 2010: The role of damselflies (Odonata: Zygoptera) as paratenic hosts in the transmission of Halipegus eccentricus (Digenea: Hemiuridae) to anurans. J. Parasitol. 96: 724-735.

Bush A.O., Lafferty K.D., Lotz J.M., Shostak A.W. 1997: Parasitology meets ecology on its own terms: Margolis et al. revisited. J. Parasitol. 83: 575-583.

Cabrera-Guzmán E., Garrido-Olvera L., León-Règagnon V. 2010: Helminth parasites of the leopard frog Lithobates sp. Colima (Amphibia: Ranidae) from Colima, Mexico. J. Parasitol. 96: 736-739.

Cabrera-Guzmán E., León-Règagnon V., Garcia-Prieto L. 2007: Helminth parasites of the leopard frog Rana cf. forreri (Amphibia: Ranidae) in Acapulco, Guerrero, Mexico. Comp. Parasitol. 74: 96-107.

CARr A. 1952: Handbook of Turtles: The Turtles of the United States, Canada, and Baja California. Cornell University Press, Ithaca, New York, 147 pp.

Cooley C., Floyd A., Dolinger A., Tucker P. 2003: Demography and diet of the painted turtle (Chrysemys picta) at high- elevation sites in southwestern Colorado. Southwest. Nat. 48: 47-53.

Corbet P.H. 1999: Dragonflies: Behavior and Ecology of Odonata. Cornell University Press, Ithaca, New York, 829 pp.

Demuth J., Buhlmann K. 1997: Diet of the turtle Deirochelys reticularia on the Savannah River Site, South Carolina. J. Herpetol. 31: 450-453.

Dillon R.T. Jr. 2000: The Ecology of Freshwater Molluscs. Cambridge University Press, Cambridge, United Kingdom, 509 pp.

Ernst C., Lovich J., Barbour R. 1994: Turtles of the United States and Canada. Smithsonian Institution Press, Washington, $578 \mathrm{pp}$.

FIELDEN A. 1960: Transmission through the last abdominal ganglion of the dragonfly Anax imperator. J. Exp. Biol. 37: 832-844.

GonzÁlez C., Hamann M. 2007: The first record of amphibians as paratenic hosts of Serpinema larvae (Nematoda; Camallanidae). Brazil. J. Biol. 67: 579-580.

Hoffman G.L. 1999: Parasites of North American Freshwater Fishes. Second edition. Cornell University Press, Ithaca, New York, $539 \mathrm{pp}$.

Leuckart R. 1876: Die menschlichen Parasiten un die von ihnen herruhred Krankheiten, II. Leipzing Heidelberg, pp. 109-112.

Martinho F. 2008: Spiny softshell turtle (Apalone spinifera, formerly Trionyx siniferus). Exotic DVM 10: 33-34.

May M.L., Dunkle S.W. 2007: Damselflies of North America, Color Supplement. Scientific Publishers, Gainesville, Florida. $165 \mathrm{pp}$.

Moravec F., ŠKoríkoví B. 1998: Amphibians and larvae of aquatic insects as new paratenic hosts of Anguillicola crassus (Nematoda: Dracunculoidea), a swimbladder parasite of eels. Dis. Aquat. Org. 34: 217-222.

MoraveC F.,VArgas-VÁzQuez J. 1998a: Some endohelminths from the freshwater turtle Trachemys scripta from Yucatan, Mexico. J. Nat. Hist. 32: 455-468.

Moravec F., Vargas-VÁzquez J. 1998b: Fish as paratenic hosts of Serpinema trispinosum (Leidy, 1852) (Nematoda: Camallanidae). J. Parasitol. 84: 454-456.

Novak, C.W., GoATER T.M. 2013: Introduced bullfrogs and their parasites: Haematoloechus longiplexus (Trematoda) exploits diverse damselfly intermediate hosts on Vancouver Island. J. Parasitol. 99: 59-63

Platt S., Hall C., Liu H., Borg C. 2009: Wet-season food habits and intersexual dietary overlap of Florida box turtles (Terrapene 
carolina bauri) on National Key Deer Wildlife Refuge, Florida. Southeast. Nat. 8: 335-346.

Pritchard M.H., Kruse G.O.W. 1982: The Collection and Preservation of Animal Parasites. University of Nebraska Press, Lincoln, Nebraska, 141 pp.

Rhoden H.R., Bolek M.G. 2011: Distribution and reproductive strategies of Gyrinicola batrachiensis (Oxyuroidea: Pharyngodonidae) in larvae of eight species of amphibians from Nebraska. J. Parasitol. 97: 629-635.

Rowe J. 1992: Dietary habits of the Blanding's turtle (Emydoidea blandingi) in northeastern Illinois. J. Herpetol. 26: 111-114.

Seidel M. 1990: Growth and population of the slider turtle, Trachemys decussate, on Grand Cayman Island. J. Herpetol. 24: 191-196.

Sokal R.R., RohlF J.F. 1981: Biometry. Second edition. W.H. Freeman and Company, New York, 859 pp.
Thorp J.H., Covich A.P. 2001: Ecology and Classification of North American Freshwater Invertebrates. Second edition. Academic Press, San Diego, California, 1056 pp.

Vhora M.S., Bolek M.G. 2013: New host and distribution records for Aplectana hamatospicula (Ascaridida: Cosmocercidae) in Gastrophryne olivacea (Anura: Microhylidae) from the Great Plains U.S.A. J. Parasitol. 99: 427-420.

Westfall M.J., May M.L. 2006: Damselflies of North America. Revised Edition. Scientific Publishers, Gainesville, Florida, 503 pp.

WiLLIS O. 1971: A mermithid nematode in naiads of damselflies (Odonata: Coenagrionidae). Fla. Entomol. 54: 321-324.

YeH L.S. 1960: On a reconstruction of the genus Camallanus Railliet and Henry, 1915. J. Helminthol. 34: 117-124.

Zimmermann M.R., Luth K.E., Esch G.W. 2011: The unusual life cycle of Daubaylia potomaca, a nematode parasite of Helisoma anceps. J. Parasitol. 97: 430-434.

Cite this article as: Wiles C.M., Bolek M.G. 2015: Damselflies (Zygoptera) as paratenic hosts for Serpinema trispinosum and its report from turtle hosts from Oklahoma, USA. Folia Parasitol. 62: 019. 